\title{
Technology enhanced learning in teachers' professional development
}

\author{
Lasma Ulmane-Ozolina ${ }^{1}$, Anita Jansone ${ }^{1}$, Ilva Magazeina ${ }^{1}$, Dina Barute ${ }^{1}$ \\ ${ }^{1}$ Departement of Science and Engineering, Liepaja University
}

\section{Article Info}

Received Dec 31 2018

Keyword:
Computing
E-learning
TEL
Teachers' professional
development
Webinar

Corresponding Author:

Lasma Ulmane-Ozolina,

\begin{abstract}
There is a lot of attention focused on the development of digital competency already in early age. One of the key person is teacher. To develop teachers' digital skills, technology enhanced learning can be used in their professional development. There is large change in Latvia' education system. One of the changes is subject "Computing" that will be compulsory in all schools from 2019. From 2015 Liepaja University participates in a pilot project for this purpose and is only one that offers teachers' professional development courses for the subject. Article's aim is to introduce "Computing" course, mainly the last one what was organized mostly in webinar mode. The article shows first data from teachers' survey about their attitude to a webinar. This is the first article in a series about research made on this course.
\end{abstract}

Departement of Science and Engineering,

Liepaja University,

Liela street 14, Liepaja, Latvia.

Email: lasma.ulmane-ozolina@liepu.lv

\section{Introduction}

Teacher profession is one of those that require continuous professional development (PD). That means that teachers participate in lifelong learning. In some countries, there are State's instructions about how many hours teachers must spend on their professional development. For example, teachers in Latvia must spend 36 hours in three year period for professional development and planning it in cooperation with the administrator of the institution where they teach. MENTEP project's (with 14 participating countries) results show that in 9 countries professional development for teachers is compulsory and only in 5 countries professional development is not obligatory [MENTEP Deliverable 6.1, 1]. Teachers in Latvia can choose only the municipality or Ministry of Education and Science approved professional development courses. It makes a very limited choice because if teacher participate in the course, for example, offered by European Schoolnet Academy - it can't be officially included in their professional development.

The aim of the article is to introduce Liepaja University's experience in providing professional development courses for teachers, in this case - course "Computing". From 2015 in 150 Latvia's schools there is pilot project that introduces Computing lessons from first grade at schools; from 2019 it will be compulsory subject in all schools. The course is interesting for research because it is provided in blended learning mode where face-to-face lessons are combined with e-learning (Liepaja University uses Moodle) and webinars. The researched group consisted of 64 teachers. The research on this course is in the beginning stage.

In theory - teachers preparing children for the digital era and must implement the development of digital competence in their teaching praxis. But do teachers themselves are willing to participate in technology enhanced learning? 


\section{Professional development}

There are many factors that impact teachers' professional development, like, teachers overload, an improper offer of professional development, high costs and lack of motivation to participate in professional development [2]. "Teachers in Latvia" report shows that teachers do not participate in proffesional development because of (1) expensive/unaffordable courses (30\%), (2) possibilities to adjust to work schedule (29\%), (3) lack of appropriate courses/ activities (23\%), teachers are not motivated (22\%) and a lack of time because of family responsibilities (22\%) [OECD TALIS, 3].

Latvian teachers participates in PD activities a lot because it is compulsory. Data shows that teachers participates in courses and workshops (89\%), conferences on education issues (60\%) and observation visits to other schools (52\%). Data also shows that Latvian teachers participates less in in-service training (9\%) and individual or collaborative research $(29 \%)$. As report says, Latvia's teachers spend almost the same number of days than average participating in PD activities in the past 12 months. On average teachers spend eight days on courses and workshops (the same as eight days on average for all TALIS countries) [3]. The high percentage of participation in PD can be explained by Cabinets rules on obligatory PD.

In 2006 the European Parliament and the European Council recommended that digital competence is one of the basic competencies for lifelong learning. In 2016 "DigComp 2.0: The Digital Competence Framework for Citizens. "Update Phase 1: the Conceptual Reference Model" was published. This framework offers 5 competence areas for citizens - Information and data literacy, Communication and collaboration, Digital content creation, Safety, Problem-solving. These competency areas were offered for self-evaluation for the small group of teachers in Latvia to make the first impression about situation on digital competences. Teachers were asked to evaluate their digital skills based on eight competence levels ( 1 - foundation, 8 - high specialized) (Fig.1).

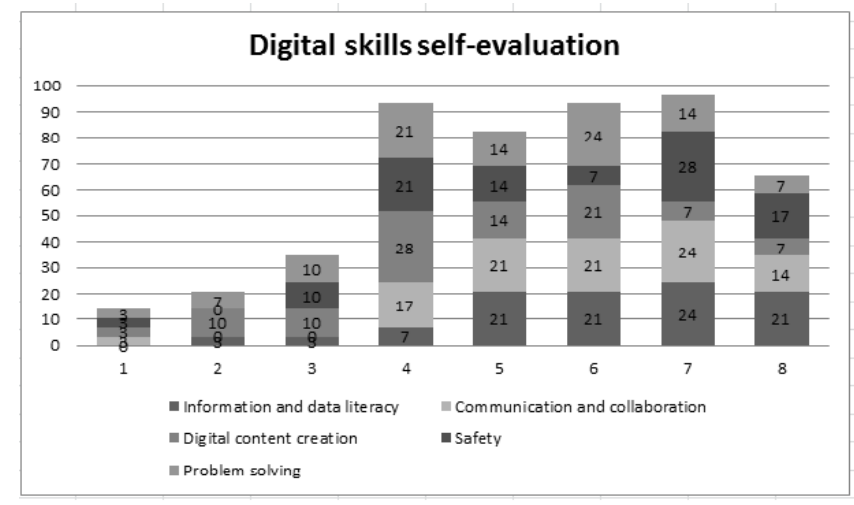

Figure 1.Digital skills' self-evaluation.

European Framework for the Digital Competence of Educators [4] offers six digital competence areas connected to educators' professional competence, educators' pedagogic competencies, and learners' competence. The purpose of this article is to study educators' professional competence area and specifically digital continuous professional development - use of digital sources and its use for continuous professional development.

In 2015, when Liepaja University started to provide "Computing" course, there was the rule in Latvia (till September of 2018), that only 30\% of the PD course can be in distance education mode. So, it automatically excluded e-learning, online courses and MOOC courses from Latvia's teachers PD. If it is compared with results published in MENTEP project deliverable, then all participating countries (France, Estonia, Greece, Czech Republic, Italy, Cyprus, Lithuania, Spain, Denmark, Slovenia, Finland, Portugal, Norway, and Scotland) offer online courses for teachers' PD [1]. The course was developed as blendedlearning course. There were face-to-face lessons, webinars, and e-learning mode (Moodle). There are new rules from September 2018 that doesn't determine PD course mode. It means that there is open space now for technology enhanced learning in teachers' PD in Latvia.

Effective professional development is needed to help teachers learn and refine the pedagogies required to teach learners' skills required in the 21st century [5], however, research has shown that many PD initiatives appear ineffective in supporting changes in teacher practices and student learning [6]. Very often 
teachers participate in PD only to get certified for demanded learning hours [7] and there is a need to make teachers more motivated [8] to gain new knowledge and skills. The large effort on motivation is teachers' pedagogical belief [9]. The question is does technology enhanced learning helps to engage teachers more in learning process, especially - if they are computing teachers.

Liepaja University has a chance to provide professional development courses for teachers participating in pilot project. There are several possibilities - 12, 32, 160 and 240 hours' courses. Course length depends on teachers' previous education, declared by Cabinet. 160 and 240 hours courses are in blended learning mode. At the course beginning there are face-to-face sessions followed by some webinars. In 2018240 hours course consisted of webinar sessions (52 in total) and some face-to-face lessons - in the beginning, middle and at the end of the course - 22 in total. There are 8 lecturers in the course. Topic about robotics is always in face-to-face because of need of real robots for learning.

OECD TALIS 2013 [3] data show that Latvia's teachers want professional development mostly on new technologies $(24,3 \%)$ as well as $19,4 \%$ of teachers admit that there is need to develop ICT skills for teaching.

\section{Technology enhanced learning}

There is not one common definition of technology enhanced learning. Sometimes it is used as a synonym for e-learning. But it is always meant to describe the application of technology to teaching and learning [10]. The use of technology in teacher PD must enhance their learning experience. One reason to use technology in computing course is to make teachers own experience on technology usage in learning. Technology enhanced learning offers not so much a technological or a cost challenge as a pedagogic one [5].

To enhance teaching and learning by technology, Liepaja University besides face-to-face classes uses elearning tool Moodle and webinar. A. Kirkwood and L. Price [10] states that technology can be used to (1) replicate existing teaching practices, (2) supplementing existing teaching and (3) transforming teaching and/or learning processes and outcomes. Course authors' idea was to transform the learning process and bring it closer to learner as well as they put a lot of efforts to consider what course content pedagogically can be transformed into webinar mode.

\subsection{Webinar}

Webinar is Web 2.0 tool that allows synchronously participate or lead a presentation, lecture, workshop or seminar.. Webinar's advantage is interactive elements, the ability to give, receive and discuss information in real-time [11]. Liepaja University chose ZOOM video webinar system. It is easy to use as well as for participants and organizers.

Main advantages of the webinar are:

- cost and time resource reduction (travel expenses, accommodation, time spent on travel to University or course avenue);

- learners can participate online but can also view recordings;

- possibility to interact with lecturer and students online (open microphone, text chat, e-mail, poll);

- ability to share or download additional digital material at any time during the webinar [12]

But there are also disadvantages of the webinar:

- technical problems;

- the participants' mood and motivation is difficult for the speaker to determine;

- participants could easily be distracted i.e. due to their surroundings, or because they know they aren't being watched;

- the interaction between speaker and participant is often reduced to a minimum; 
- the time frame is almost always binding - sometimes it isn't possible to log in later. [13]

One of the positive sides of webinar in learning in our case is that learners can save time and money on travel to University because there is wide range of teachers' home geography (Fig.2).

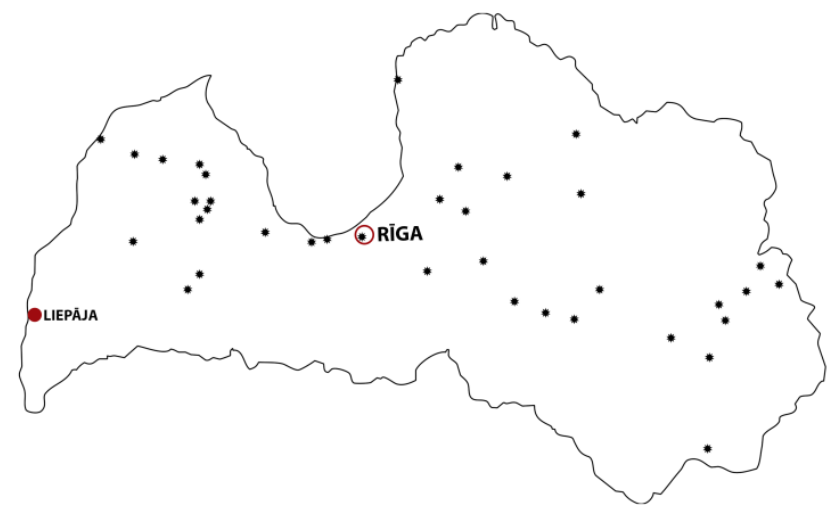

Figure. 2: Teachers' home geography.

It also gives an opportunity for teachers to watch seminars recordings as they need. To get more personal feedback (in the last course there were 64 participants), teachers were divided in groups of 16 and each group has their own support person. It was done in order to support active participation in the webinar, based on research made by Jung, I., Choi, S., Lim, C., \& Leem, J. [14]. To provide united feedback and support for teachers, all support persons together with lecturer were in one room.

Topics chosen for webinars were those that are pedagogically appropriate for webinars. For example, IT and security, Work with office apps, some methodological issues. There were also webinars on programming languages, but there were introductory face-to-face sessions before.

In survey (29 teachers from 64 participated) teachers as main advantages of the webinar call possibility to view recorded webinar $(79,3 \%)$ and possibility to participate in webinar from their own place $(65,5 \%) .44,8 \%$ of teachers who participated in webinars admits, that advantage was also saving of time resources.

As disadvantages teachers name adjusting to webinar timetable $-72,4 \%$ of respondents, disturbing context (being at home made hard to concentrate on learning - 27,6\%. This is very important finding according to activity theory by L. Vygotsky (1978) and developed later by Engeström (1993) knowledge construction relates to the context [15]. But this topic of research will be expanded in future research activities. There can be made research does teacher's performance in course relates to his/her complains about the disturbing context in webinars. $20,7 \%$ of teachers say that there were technical problems during webinars that is one of the main risks for webinars per se not only from participants side but from organizer side as well.

\subsection{E-learning}

As mentioned before, e-learning is used as a synonym for technology enhanced learning.

The advantages of e-learning can be explained by the slogan of e-learning - any time, any place, anywhere. Use of e-learning gives students the freedom to access learning materials in time best for them, to follow instructors' instructions, manage homework, participate in the communication.

Liepaja University as e-learning environment uses Moodle. For PD course "Computing" Moodle is used as an environment for webinar records, additional learning materials, access to presentation materials, 
discussion forums as well as the place to submit homework. Every lecturer has its own course place and is free to use it as needed but usage must be meaningful.

Moodle is used as support environment not so much as for e-learning aims because of specific of course topics and teachers previous knowledge course authors decision is to put more effort on face-to-face sessions and on webinars.

\section{Conclusion}

Research made on teachers' professional development course "Computing" is in the very beginning. First results show that overall teachers are satisfied with course organization, especially webinars. Webinar use allows teacher participates in the course independently from their place of residence as well as it is beneficiary for course lecturers. Topics for webinars were carefully chosen not to lose pedagogical value. Future research will be made on teachers' evaluation of course (previous experience, the content of webinars, lecturers' evaluation, suggestions, activity in the course and ectr.); there will be comparative research on course modes to enrich course content and mode.

Teachers' professional development is very important and it makes impact on their students as well. That is why there must be research made on PD to offer as a pedagogically valuable course (in terms of content and technology) as possible.

\section{Acknowledgement}

The article is written with the financial support of European Regional Development Fund project Nr.1.1.1.5/18/I/018 Pētniecības, inovāciju un starptautiskās sadarbības zinātnē veicināšana Liepājas universitātē.

\section{References}

1. Taddeo, G., Cigognini, E.M., Parigi, L., Blamire R. Certification of teachers' digital competence Current approaches and future opportunities. MENTEP Deliverable 6.1; 2016

2. Geske, A., Kiris, K., Kozlovska, A., Ozola, A., Rečs, N., Spridzāne, K. Skolotāji Latvijā un pasaulē (A.Geskes redakcijā). Monogrāfiju sērija Izglītības pētniecība Latvijā Nr.6. Rīga: LU PPMF Izglītības pētniecības institūts; 2015. 293 lpp.

3. TALIS 2013 Results: An International Perspective on Teaching and Learning [Internet]. OECD; 2014 [cited 2018 Dec 18] Available from: http://www.oecd.org/latvia/TALIS-2013-country-note-Latvia.pdf

4. Redecker, C. European Framework for the Digital Competence of Educators: DigCompEdu. Punie, Y. (ed). EUR 28775 EN. Publications Office of the European Union, Luxembourg; 2017, ISBN 978-92-7973494-6, doi:10.2760/159770, JRC107466

5. OECD "The potential of technology-supported learning", in Innovating Education and Educating for Innovation: The Power of Digital Technologies and Skills [Internet], OECD Publishing, Paris; 2016 [cited 2018 Dec 18] Available from: https://doi.org/10.1787/9789264265097-6-en.

6. Darling-Hammond, L., Hyler, M. E., Gardner, M. Effective Teacher Professional Development. Palo Alto, CA: Learning Policy Institute; 2017.

7. Easton, L. B. From Professional Development to Professional Learning. [Internet] Phi Delta Kappan, 89(10); 2008 [cited 2018 Dec 18]. 755-761. Available from: https://doi.org/10.1177/003172170808901014

8. Hansson, H. Teachers' professional development for the technology-enhanced classroom in the school of tomorrow. E-Learning and Digital Media; 2006 3(4), 552-564.

9. Albion, P. R., Tondeur, J., Forkosh-Baruch, A., \& Peeraer, J. Teachers' professional development for ICT integration: Towards a reciprocal relationship between research and practice. Education and Information Technologies; 2015 20(4), 655-673.

10. Kirkwood, A., \& Price, L. Technology-enhanced learning and teaching in higher education: what is 'enhanced' and how do we know? A critical literature review. Learning, media and technology; 2014 39(1), 6-36.

11. Beal Vangie. Webinar (Web-based seminar) [Internet]. [cited 2018 Dec 18]. Available from: https://www.webopedia.com/TERM/W/ Webinar.html 
12. Wang, S. K., \& Hsu, H. Y. Use of the webinar tool (Elluminate) to support training: The effects of webinar-learning implementation from student-trainers' perspective. Journal of interactive online learning; 2008 7(3), 175-194.

13. Webinar: definition, basics, and possible uses [Internet]. [cited 2018 Dec 18] Available from: //https://www.ionos.com/digitalguide/online-marketing/online-sales/webinars-advantages-features-andpossible-uses/ Retrieved 18.12.2018.

14. Jung, I., Choi, S., Lim, C., \& Leem, J. Effects of different types of interaction on learning achievement, satisfaction and participation in web-based instruction. Innovations in education and teaching international; 2002 39(2), 153-162.

15. Govender, I. The learning context: Influence on learning to program. Computers \& Education; 2009 53(4), 1218-1230. 